\title{
The Chicago Tradition and Commercial Bank Seigniorage
}

\author{
Erotokritos Varelas ${ }^{1} \&$ Gerasimos T. Soldatos ${ }^{2}$ \\ ${ }^{1}$ University of Macedonia, 54006 Thessaloniki, Greece \\ ${ }^{2}$ American University of Athens, 15232 Athens, Greece \\ Correspondence: Erotokritos Varelas, University of Macedonia, 54006 Thessaloniki, Greece. E-mail: \\ varelas@uom.gr
}

Received: January 12, 2014

Accepted: February 4, 2014

Online Published: March 1, 2014

doi:10.5430/rwe.v5n1p29

URL: http://dx.doi.org/10.5430/rwe.v5n1p29

\begin{abstract}
Chicago rule is shown to be the unique optimal monetary policy rule from the viewpoint of an intergenerational welfare-maximizing social planner. But, in the absence of commercial banking, it really mandates the elimination of the public sector, because it involves the elimination of central bank seigniorage and hence, of the government spending based on this seigniorage, rendering subsequently tax finance incapable of sustaining alone such spending. In the presence of commercial banking, the government does have the option of benefiting from commercial bank seigniorage by borrowing it countercyclically as implied by Chicago rule, which is found to operate like a full-reserve requirement.
\end{abstract}

Keywords: Chicago rule, Chicago plan, seigniorage, intergenerational modeling

\section{Introduction}

In 1969, Milton Friedman put forward the view that: "Our final rule for the optimum quantity of money is that it will be attained by a rate of price deflation that makes the nominal rate of interest equal to zero" (p. 34). This proposal has become known as Friedman's or Chicago rule, given that it was being made within the broader context of the Chicago school of thought. In 1948 and within the same precisely context, Friedman had previously endorsed Henry Simons' "Positive Program for Laissez Faire", (Simons 1934, 1936), elaborating inter alia upon the following theses for a "Monetary and Fiscal Framework for Economic Stability", as Friedman had entitled his endorsement: "The adoption of 100 per cent reserves" (p. 247), and the mandate that the "Government would not issue interest-bearing securities to the public; the Federal Reserve System would not operate in the open market" (p. 250). To this, the balanced-budget argument has to be added as part of the Chicago School tradition: "An appropriate combination of monetary and fiscal policy can and should be used to prevent inflation. Such a combination would consist of a roughly balanced budget and whatever level of monetary ease or tightness is required to prevent civilian expenditures from producing inflation" (Friedman 1953, pp.272-273).

That is, the Chicago School policy tradition encompasses the Chicago rule, the $100 \%$ reserve requirement ratio, no open-market operations, and a balanced budget. The balanced-budget argument prompts one to see Chicago rule designed to act inter alia countercyclically too, from the viewpoint of monetary policy and in combination with the remaining three premises of this tradition. In this comment, we maintain that from an intergenerational point of view, Chicago rule is consistent with these premises only under government borrowing of commercial bank seigniorage. Chicago rule nullifies by definition central bank seigniorage and hence, government expenditure based on money issuance. So, taking recourse to commercial banks to obtain the purchasing power of their own seigniorage is necessary, because it would be seriously suboptimal to sustain government expenditure based exclusively on tax revenue given also that no open-market operations are allowed. In the absence of central bank seigniorage, the only solution left is to take advantage of commercial bank seigniorage, borrowing it during deflation to pay it back during inflation. Borrowing it to spend it and boost the economy when circumstances dictate so, and paying it back when the state of the economy commands government spending contraction.

But, which exactly is the commercial bank seigniorage under Chicago rule? It is the opportunity cost of holding reserves, namely, the difference between the lending and the deposit interest rate, the foregone profit rate. The lending interest rate is the nominal interest rate, which is set equal to zero and hence, commercial bank seigniorage is identified with the deposit rate times the volume of deposits. This would be the case under a full-reserve requirement, 
too. In deflation, a zero nominal interest rate implies a positive real rate of interest to which the deposit rate should be equal given perfect or nearly perfect competition in commercial banking. This is the case when the government borrows from the banks the deposit rate payments owed by them to the public. In inflation, the deposit rate is as negative as the real interest rate is, and it is the case when the government pays the loans back to the banks. So, how much exactly should the government be borrowing in principle without jeopardizing liquidity? People must be able to withdraw from the banks any amount at any time. Two are the scales of the answer to this question.

First, note that the deposit rate is also the public's opportunity cost of holding cash instead of a deposit account with a bank. As such, it is like a uniform commodity tax, which by optimal taxation theory, should be equal ideally with the tax rate under linear direct taxation. Therefore, the optimal percentage of deposit-rate payments borrowed by the government should be the one which is consistent with this equality. Spending based on tax revenue should be equal with spending based on commercial bank seigniorage in compliance as a total with the balanced-budget rule. That is, totally, at disequilibrium, the public sector should be expanding/contracting at the same rate as that of the symmetric fiscal and monetary expansion/contraction prescribed by Chicago rule.

The answer to the second scale of the last question regarding liquidity risks might be a $100 \%$ deposit insurance, which is however not in the spirit of the Chicago School; the 100\% reserve requirement ratio is. In July 1939, Douglas et al. advanced "A Program for Monetary Reform"- already known as "Chicago Plan"- having adopted Irving Fisher's (1936) version of the full-reserve thesis: The key feature of this plan was that it called for the separation of the monetary and credit functions of the banking system, first by requiring $100 \%$ backing of deposits by government-issued money, and second by ensuring that the financing of new bank credit can only take place through earnings that have been retained in the form of government-issued money, or through the borrowing of existing government-issued money from non-banks, but not through the creation of new deposits, ex nihilo, by banks." (Benes and Kumhof, 2012, p. 4).

IMF's Benes and Kumhof (2012), Kotlikoff and Leamer (2009) and Rothbard (2008), are some of those who still support the full-reserve requirement. But, there do exist many and strong voices against such a scheme, too. For example, according to Douglas and Dybvig (1986, p. 65-66): “...to impose a 100\% reserve requirement...restricts banks from entering the transformation business (they cannot hold illiquid assets to transform into liquid assets),... [which] is a dangerous proposal that would do substantial damage to the economy by reducing the overall amount of liquidity." And, there were always voices pointing to the similarity of this requirement with the otherwise harmless as claimed $100 \%$ deposit insurance option from the viewpoint of safeguarding against illiquidity. This is a reason why the interest in the $100 \%$ reserve requirement subsided after the emergence of the FDIC and why one of the reactions to "The Chicago Plan Revisited" of Benes and Kumhof (2012) is that the modern banking system is more or less consistent with it (see e.g. Giraud and Pottier 2012 of the Paris School of Economics). It appears to be ignored that the Chicago School policy tradition is one put forward in a first-best setting whereas opposition wonders what is going to happen in a second-best environment. Therefore, the government borrowing of deposit-rate payments should be implemented within the broader context of the full-reserve requirement. After all, according to Keister and McAndrews (2009), there may be instances of bank lending not out of bank reserves but out of newly created deposit money ex nihilo.

In sum, the cornerstone of the Chicago tradition appears to be the Chicago rule under a broader, a social planner's point of view rather than in strict economistic terms. Under commercial banking, the Chicago rule acts like a full-reserve requirement, but such a requirement has merit on its own grounds in protecting against illiquidity shocks. The four pillars of this tradition aim at acting as a built-in-the-system stabilizer, to become an institutional feature of a market socioeconomy in line rather than at discrepancy with its market underpinnings. Underpinnings, having come out of the historic evolution of the socioeconomy as the first-best alternative to social welfare maximization. But, is the Chicago rule the only optimal rule and by extension, is the Chicago route the only one available to a planner aiming at maximizing this welfare vis a vis the multiplicity of the market-interventionist discretionary policy-making? And, even if it is, what kind of societal arrangement would prompt the emergence of such a commercial banking system that would make this rule and the Chicago tradition in general applicable?

These are critical questions that may come up only under an overlapping generations modeling in which, however, Chicago rule is found often to be one only out of many other similar optimal monetary policy rules or non-optimal at all. The first part of the next Section shortens out the matter of uniqueness in the standard central-bank only environment. It is argued that overlapping generations models do not incorporate explicitly a social welfare function in terms of the generational utility functions so that the social-welfare maximizing and thereby, Chicago rule may be picked out of the many other optimal rules. The second part of the next section, introduces commercial banking as a 
non-market means of ensuring efficient intergenerational transfers. This is the view of commercial banking under which the nexus between commercial bank seigniorage and Chicago rule-cum-Chicago tradition are discussed in the same subsection. The third part of Section 2 emphasizes the countercyclical character of Chicago Economics under a social-planner minded government and banking; otherwise political opportunism and financial speculation may incite a sovereign debt crisis leaving little room for rules. Section 3 concludes with speculations on the political economy surrounding this discussion.

\section{The Intergenerational Perspecitive}

\subsection{The Chicago Rule under Central Only Banking}

Contrary to money-in-the-utility-function infinitely-lived representative agent models, the cash-in-advance-constraint overlapping-generations models postulate two usually types of agents, young, $y$, and old, $o$. Hence, although the intertemporal distribution of taxes and transfers is inconsequential in the former models (Ricardian equivalence), it does matter in the latter at least in so far as Chicago rule is concerned. To cite characteristically from Gahvari (2007, Abstract, p. 581): "In overlapping generations models, money growth creates intergenerational wealth effects and leads to the breakdown of the Friedman rule; the rule can be restored via lump-sum tax and transfers that neutralize these wealth transfers. Additionally, and in contrast to money-in-the-utility-function models, the Friedman rule is not unique in cash-in-advance-constraint models of money: A continuum of combinations of money growth rates and consumption taxes implement the first-best allocation."

According to this note, the problem with the overlapping-generations models is that ever since Diamond (1965), it has become standard practice to be based on a utility function of the type:

$$
u_{t}^{y}=u\left(c_{t}^{y}, c_{t+1}^{o}\right)
$$

where $u, c$, and $t$ denote utility, consumption, and time, respectively; (see e.g. Gahvari, 2009, and the subsequent literature). This function describes preferences on the part of two concurrent generations, $y$ and $o$. But, these are two different individuals and a social welfare function, i.e. a function of the individual utility functions of the concurrent $y$ and $o$, should be occupied instead of (1). So, what (1) does in essence is to have equated these functions with the corresponding consumption levels,

$$
v^{y}\left(c_{t}^{y}\right)=c_{t}^{y} \text { and } v^{o}\left(c_{t+1}^{o}\right)=c_{t+1}^{o} .
$$

Under these circumstances, the utility, $v^{y}-v^{o}$, space and the consumption, $c_{t}-c_{t+1}$, or the same, $c^{y}-c^{o}$, space coincide, and the social indifference curves have the same slope as the utility possibility frontier does. The absolute value of the slope of both would be,

$$
\frac{d v^{o}}{d v^{y}}=\frac{c^{y}}{c^{o}}=\frac{1}{1+r}
$$

which is the cotangent of the angle with the horizontal axis; $r$ presumably is the real rate of interest.

The result, of course, is indeterminacy and non-uniqueness of equilibrium, and the equilibrium which is of concern here is the one which depends on the consumption tax $\tau$ on the young used along with the issuance of new money at the rate $\theta$ to subsidize elderly consumption, $c_{t+1}$. Letting $\alpha<1$ be the fraction of $c_{t+1}$ financed through $\theta$, at steady state when $c_{t}=c_{t+1}=c$ and when of course Friedman's rule holds, the value of the goods that may be obtained by the elderly through $\theta$ should be the same with the value that may be obtained through $\tau$ given that $\tau$ applies to the consumption of the elderly too, because it consists of goods bought from the young. That is, $\theta a c=\tau(1+\theta) c=>$

$$
\theta=\frac{\tau}{\alpha-\tau}
$$

This is the relationship between $\theta$ and $\tau$ at the point of the utility possibility frontier at which the social indifference curve should be tangent at steady state. Under "Diamond $v$ functions" this frontier as well as the social indifference curves would be linear of the same slope, and any equilibrium would be invariant to changes in $\theta$ and/or $\tau$ as indeed the following considerations suggest:

Note that at equilibrium, $i=0$, which from $1+i=(1+r)(1+\pi)$ implies that $1 /(1+r)=1+\pi$ and hence, that

$$
\frac{d v^{o}}{d v^{y}}=\frac{c^{y}}{c^{o}}=\frac{1}{1+r}=1+\pi
$$

where $i$ is the nominal interest rate, and $\pi$ is the rate of inflation. Next, note that at equilibrium, $1+\pi=1+\theta$ (see e.g. Nelson, 2008) and hence, 


$$
\frac{d v^{o}}{d v^{y}}=\frac{c^{y}}{c^{o}}=\frac{1}{1+r}=1+\pi=1+\theta
$$

And, finally, note that this relationship can be consistent with the relationship $\theta=\tau /(\alpha-\tau)$ only if $1+\theta=a=>\theta=\tau$ : $\theta$ and $\tau$ should matter the same under equilibrium regardless how large or small are in absolute value as, indeed, in equilibrium,

$$
\frac{d v^{o}}{d v^{y}}=a .
$$

Friedman's rule under steady state is indeterminate due to the indeterminacy of general equilibrium.

But note that we have an indeterminacy result with respect to the absolute values involved in $\theta=\tau$, including the possibility of $\theta=\tau=0$ as well. It is a possibility according to which: If $\theta$ and $\tau$ do not matter in determining equilibrium, why have them then and not set them equal to zero. We will immediately see that the equilibrium indeterminacy under Diamond $\mathrm{v}$ functions is consistent only with this possibility: First, setting $\tau=\alpha=0$ in (2), the fraction $\tau /(\alpha-\tau)$ becomes $\tau / 0$, which is not sensible mathematically per se, anyway, and since $\theta=\tau$, (2) becomes $0=0 / 0$, which is not sensible mathematically either and which certainly cannot be connected with any policy rule. Second, setting $\tau=1$ would yield $\alpha=2$, against any economic intuition. Third, letting $\alpha=0$, the result would be that $\tau=\theta=-1$ against intuition as well. Fourth, assuming an $\alpha=1$ would produce $\tau=0$, i.e. no tax finance of government expenditure at all, which cannot be part of any policy prescription.

And, finally, by setting $\tau$ only equal to zero and hence, $\theta=0$ too, (2) becomes $0=0 / \alpha$, which does make sense mathematically and which case may be connected with Friedman's rule. Nevertheless, $\tau=\theta=0$ would be the case only if there were no public sector at all: how else would this sector be covering its expenses if not from taxation and money issuance-cum-borrowing/lending? For a government and a unique optimal monetary policy rule to exist, $\tau$ and $\theta$ should be defined over the open unit interval, with $\tau<\alpha$, and with $\tau=\theta$ in a unique way, and this can be ensured only through concave to the origin of the axes utility possibility curve.

Hung (2005, p. 715), for example, concludes that: "If only income taxation is used for financing [public investment]... then the optimal tax rate is...too high to be a practical income tax rate. However, if there is demand for money in transactions then the optimal income tax rate is...close to the practical income tax rate...[T] his result highlights the importance of allowing both income taxation and seigniorage for financing public investment in infrastructure"... And, in the bottom line, postulating a policy rule not to be having policymakers would be a contradiction in terms. Consequently, neither the case $\tau=\theta=0$ could be thought of as being in the spirit of Chicago rule, which in turn has to be appreciated only in the realm of a fractional reserve system.

The government has to be covering its expenses by relying both on taxation and seigniorage by equating at the optimum the per-unit opportunity cost of holding money with the tax rate. This is what the Chicago rule is all about from the viewpoint of a social planner's rule as it actually is supposed to be by conception. And, as soon as what is sought is optimality, this $\tau=\theta$ would be disturbed by a budget deficit and hence, should be accompanied by a balanced-budget rule.

Now, identifying the opportunity cost with seigniorage and this in turn with the negligible production cost of fiat money is certainly as wrong as to advocate one of two extremes, namely, either the elimination of taxation and of the public sector or a public sector under an exponentially increasing debt. This is the reason seigniorage has to been seen alternatively as an inflation tax (Baily 1956, Friedman 1953, 1971), as a commodity tax from the perspective of optimal taxation (Barro 1982, Mankiw 1987, Phelps 1973, Tobin, 1963) and/or related to the default risks accompanying credit money (Reich 2011) always in a growing steady-state economy rather than in a disequilibrium environment. And, this is the reason why the closely related to Chicago rule, the more practical, Friedman's k-percent rule had to be developed, too (Friedman 1960).

Seigniorage is a critical concept in understanding Chicago rule: (a) In the absence of commercial banks or the same, under a $100 \%$ reserve system and central bank only seigniorage, $\mathrm{S}$, we have that, $S=i(H / P)$, where $H$ is the monetary base and $P$ is the price level. (b) From the quantity-theory equation, $H=k P Y$ and hence, $S=i(k P Y / P)=>S=i k Y$, where $Y$ is real income and $1 / k$ is the velocity of circulation. (c) $S$ acts like a uniform commodity tax at rate $s, S=s Y$, which in view of (b) implies that $s=i k$. (d) According to the theory of optimal taxation, this tax is equivalent to linear direct taxation under rate $\tau$ and hence, $i k=\tau$. (e) Therefore, setting $i=0$ implies that $\tau=0$. There is no reason in printing money to cover the expenses of the state when the state does so in great part through seigniorage, and seigniorage is not allowed to exist by the same the state! To rely only on tax revenues would be gravely suboptimal and the state might 
as well cease to exist altogether right from the start rather than collapse under piling up budget deficits and debts.

\subsection{Chicago Rule and Commercial Bank Seigniorage}

But, in the presence of a commercial banking system regardless its fractional or not character and which benefits from commercial bank seigniorage, $V=\left[i(1-\rho)-r_{d}\right] D / P$, with a required reserve ratio $\rho \leq 1$ on deposited money $D / P=\lambda Y$ under a deposit rate $r_{d}$, and $H=F+D$, where $F$ is cash, the total, the sum $S+V=\left(i k-\lambda r_{d}\right) Y$ and subsequently, $\mathrm{s}=\left(i k-\lambda r_{d}\right)=\tau$ (see e.g. Baltensperger and Jordan, 1997). Now, $i=0$ implies that $s=-\lambda r_{d}=\tau$ but under perfect competition $r_{d}=r$ and since $i=0=>\pi=-r, r_{d}$ is as negative as $r$ is and hence, $-\lambda r_{d}>0$. This is commercial bank seigniorage even if bank profit has been squeezed to zero as we have actually assumed. It is the opportunity cost of the public per monetary unit deposited with the bank. Chicago-rule real-world relevance "begs" for an environment of commercial banking; otherwise, not even the presence of state is justifiable. The state can exist without its own seigniorage, because it can borrow it from the commercial banks, and so, it might tax people as well, preferably at the same rate.

In this and only in this case, Chicago Rule acts countercyclically: Reverse $\pi$ via equiproportional change in $\theta$ and $\tau$, ceteris paribus: If a10\% inflation takes out $10 \%$ of the purchasing power of consumers, and if the original purchasing power was the social-welfare maximizing one, restore it through symmetric monetary and fiscal contraction, ceteris paribus... As we have already seen, Chicago rule, this rule, would be a contradiction in terms without fractional commercial banking. And, we shall start justifying the emergence of such banking in the form of intergenerational banking by noting at the outset that a societal optimum would be a Pareto efficient state of affairs, a tangency of the utility possibility curve with a social indifference curve, not necessarily Nash equilibrium. It may be encompassing thereby an intergenerational equity vs. envy-freeness trade-off; a trade-off even after the second-fundamental-theorem-of-welfare-economics prescribed lump-sum taxes/transfers needed to maintain Ricardian equivalence as follows.

Envy and equitability are by definition subjective and hence, private information and there can be no Arrow-Debreu insurance markets to handle them efficiently. For example, the young may be considering that too much goes to social security and the elderly may be consuming too much out of the social-security check under a dum vivimus, vivamus (while we live, let us live) mentality. Or, Alper et al. (2008) find seigniorage to be a burden on old households, which is not compensated unambiguously by public investment, but which investment does compensate for the taxation burdening the current generation. Do the elderly favor public consumption expenditures, which the young would oppose? Indeed, envy-equitability preoccupations manifested by the young is a factor akin to the uncertain preference regarding the time of consumption mainly by the elderly, which such markets cannot handle and prompt the emergence of intergenerational banking a la Diamond and Dybvig (1983).

In a monetized market economy, all of these factors pose illiquidity threats; they may incite generational bank-runs, the protection against which is what is supposed to be dictating bank policy. Young and old have money on deposit with the bank at rates $r_{d 1}$ and $r_{d 2}$, respectively. According to Qi (1994), if the elderly have uncertain preferences about the time of consumption, the intergenerational bank can nullify the subsequent illiquidity risks through the selection of the appropriate combination of $r_{d 1}$ and $r_{d 2}$. The intergenerational bank acts in this case as a non-market and specifically, as a social-planner surrogate of efficient Arrow-Debreu insurance by providing liquidity insurance; and a similar argument may be made a priori with regard to envy-equity: Chicago rule continues holding.

Indeed, there are many contexts within which this rule has been shown to be optimal, (see, e.g. Phelps 1973, Kimbrough 1986, Guidotti and Vegh 1993, Correia and Teles 1996, Chari, Christiano, and Kehoe 1996, Ireland 1996, or Mulligan and Sala-i-Martin 1997). They are contexts which preclude liquidity preference shocks; neither envy-equity nor high discounting of the future is a shock element. Protection in the fear of random relocation by holding more cash than is optimally needed and actual relocation is an example of circumstances that may do induce liquidity preference shocks; in which case Chicago rule appears to cease being optimal. Quite instructive of this point of view is Smith's (2003) work on the role of bank intermediation under such shocks: To the extent that relocation introduces frictions that prevent the operation of the Modigliani-Miller theorem and that the altered capital structure of the bank does take its toll on growth prospects, keeping the nominal interest rate too low may be suboptimal. Under a liquidity preference shock, a social-planner intergenerational bank fostering social welfare maximization from the viewpoint of growth as well is inconsistent with Chicago's rule.

Relocation models are not genuinely overlapping generations models in that they do not postulate explicitly two separate utility functions, one for the young and one for the old; they assume instead one intertemporal utility function. Yet, their thesis is quite plausible, validated empirically, and there is no a priori reason why it should not be confirmed within an original overlapping generations environment: High/low nominal interest rates imply high/low opportunity cost of holding reserves and this in turn, high/low lending and growth and subsequently, low/high 
insurance against the risk of relocation. Consequently, the social optimality of Chicago rule should be sought not in connection with this line of reasoning, but in the fact that this reasoning describes a response to a disequilibrium shock whereas Chicago rule focuses on countering the disequilibrium with a view to long-run equilibrium. After all, although under commercial banking, the Chicago rule acts like a full-reserve requirement, following such a requirement would do protect against illiquidity shocks. It all depends on whether the social planner's concern is the cyclical short- or acyclical long-run, on whether the planner deems appropriate to manipulate the cycle as such or in combination with the institutional context of the acyclical long-run within which it is unfolding.

Indeed, the introduction of commercial banking and thereby commercial bank seigniorage and credit money from the viewpoint of intergenerational banking enriches the monetary-policy aspect of Chicago rule a lot. Noting that $V=V_{1}+V_{2}$ and letting $D_{1}=\sigma D$ and $D_{2}=(1-\sigma) D, 0 \leq \sigma \leq 1$, total seigniorage becomes, $S+V=i k Y$ - $\left[r_{d 1} \sigma+r_{d 2}(1-\sigma)\right] \lambda Y$, where now $i=r+\pi+\varphi+\psi$, with $\varphi$ being a risk premium with respect to credit money related default risks and/or bank runs, while $\psi$ is a liquidity premium in connection with relocation and liquidity preference shocks in general. Setting $i=0=>\pi=-r-\varphi-\psi$ and the term $\left[r_{d 1} \sigma+r_{d 2}(1-\sigma)\right]$ is positive to the extent the $r_{d}$ 's follow the countercyclical of the rule. Indeed, anti-inflationary monetary contraction, for example, and reduction in default risks and/or illiquidity go together.

Nevertheless, it should be stressed again that the overall countercyclical contribution of the Chicago rule may be judged too weak by someone favoring discretionary policy-making. But, such a position derives from the perspective of rules $v s$. discretion, which is not methodologically the proper context within which to judge the optimality of a rule. As a matter of fact, it is as improper methodologically as to be identifying $i=0$ only with $r+\pi=0$, taking the presence of factors like $\varphi$ and $\psi$ as tokens of Chicago rule falsification. $r=[(1+i) /(1+\pi)]-1 \approx i-\pi$ is the linear approximation of the Fisher equation, but the focus of Chicago rule is supply of real money consistent with the horizontal intercept of the money demand curve in the real money (horizontal axis)-nominal interest rate (vertical axis) space and hence, consistent with $i=0$ whatever thereby this $i$ may be including.

\subsection{Chicago School and Countercyclicality versus Political Opportunism and Financial Speculation}

In practice, the no-open-market-operations requirement might be relaxed if circumstances require so even if the other mandates of Chicago Tradition are preserved. This is what had in mind when according e.g. to Tavlas (1997, p.153): "Contrary to recent interpretations, Chicago economists advanced the efficacy of monetary policy as the means of escaping from the Great Depression, provided that such a policy was implemented by the use of budget deficits to generate monetary expansion. The use of the quantity theory of money to provide a theoretical rationale for budget deficits distinguished the Chicago economists from other quantity theorists and left them less susceptible to the Keynesian revolution. The claim that Harvard was an important center for monetary research in the early 1930s is refuted." That is, countercyclicality is built in rules; the rules have been advanced as built-in institutionally stabilizers.

Next note that according, for instance, to European Commission Economic Papers as that by Berti et al. (2013), the debt-to-GDP ratio, $\delta$, generated by continuous deficit spending is at time $t$ under zero-stock flow adjustments: $\delta_{t}=\delta_{t-1}\left[\left(1+i_{t}\right) /\left(1+g_{t}\right)\right]-$ pbal $_{t}$, where $1+g_{t}=Y_{t} / Y_{t-1}$ with $Y=G D P$ and pbal is the primary budget balance. Setting according to Chicago School, pbal $=0$ and $i=0$, yields that $\delta_{t} / \delta_{t-l=1} 1 /\left(1+g_{t}\right)$, i.e. that the change in $\delta$ is an inverse function of the rate of growth g, with $d\left(\delta_{t} / \delta_{t-1}\right) / d g_{t}=-1 /\left(1+g_{t}\right)^{2}<0$, and $d^{2}\left(\delta_{t} / \delta_{t-1}\right) / d g_{t}^{2}=2 /\left(1+g_{t}\right)^{3}>0$. Once the ideal of $\delta=0$ has been disturbed, adherence to the rest of Chicago tradition rules will restore equilibrium at an increasing pace. This is precisely the essence of Chicago Economics once the economy is found off equilibrium suffices to have social-planner attitude on the part of the government and of the financial system.

But, if instead of abiding to the other rules of the Chicago School, the government continues in the case of $\delta>0$, spending recklessly, a debt crisis will be given rise like the recent one in south eurozone. The extreme case of Greece directly addresses the intergenerational nature of banking, when as, for instance, the Carnegie Endowment for International Pease is urging already from 2010, that Greece should "[s]eriously consider restructuring the debt, allowing time for creditors to prepare to facilitate progress on an agreed solution" (Dadush et al. 2010, p.119). And, the time contemplated for Greece is until 2050, which clearly points to the intergenerational character of banking like no other historical paradigm given that most of the Greek debt is held by commercial banks.

The overall example of the debt crisis in south eurozone manifests the consequences from having opportunistic non-social-planner minded governments in response to a speculative non-social-planner minded financial system. The diagnosis for the crisis is unanimously (see e.g. the "Symposium: The Euro" in the Summer 2013 issue of the Journal of Economic Perspectives) that the advancement of a single legal tender, euro, area in Europe, lowered significantly borrowing costs for the south of the continent, which reduction coupled with the optimism about the 
future of the euro area, resulted in massive capital movements towards the south, which however were used to raise spending there in all domains. The 2008-09 Lehman Crisis cancelled these capital inflow trends abruptly, uncovering huge private and public debts, and along with them, the speculative character of the international financial system and the opportunism of "fiscal-free-lunch" motivated south eurozone governments.

It is circumstances like these, political opportunism and financial speculation in the place of responsible social planner roles, and not any inappropriateness on the part of Chicago Economics that makes these Economics inoperative and that makes Cottarelli (2012) or DeLong et al. (2012) rather than the European Central Bank-European Commission-International Monetary Fund Troika-prescribed austerity (see e.g. Gordon et al. 2013) be right in confronting sovereign debt crisis: "...at the zero bound, where the central bank cannot or will not but in any event does not perform its full role in stabilization policy, fiscal policy has the stabilization policy mission that others have convincingly argued it lacks in normal time." (DeLong et al. 2012, p.233). As, Diagram 1 illustrates, post-2009 eurozone is experiencing a near zero bound reality, which it meant for the depressed south eurozone that under its commitment to short-term deficit reductions towards long-term sustainability, it should not be surprised when seeing that: "growth slows more than expected ... [they are] inclined to preserve their short term plans through additional tightening, even if

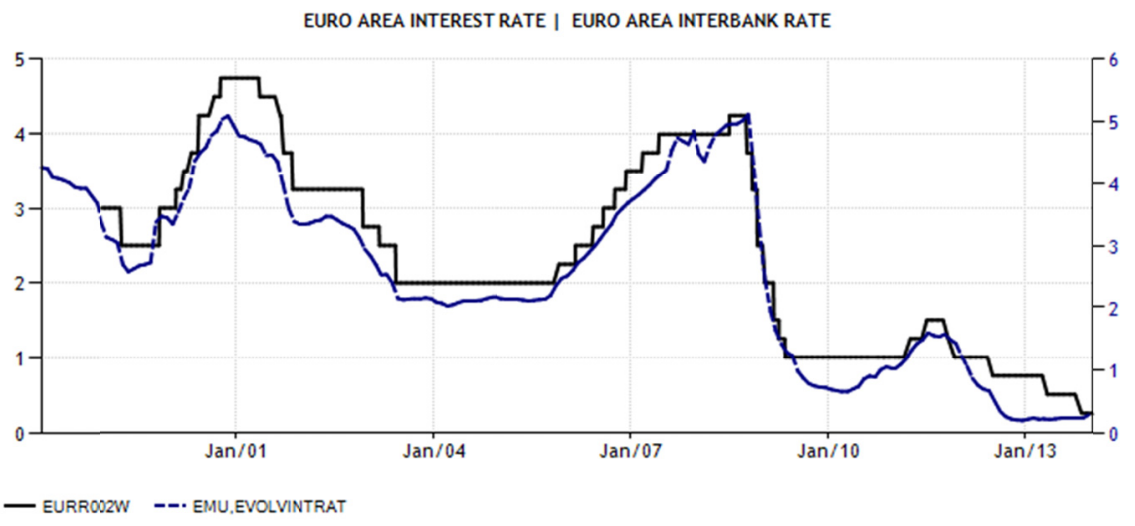

Diagram 1. Post Lehman Crisis Eurozone Nearing the Zero Bound

Source: http://www.tradingeconomics.com/euro-area/interest-rate

it hurts growth more ... my bottom line: unless you have to, you shouldn't ... interest rates could actually rise [even] as the deficit falls ... [if] growth falls enough as a result of a fiscal tightening" (Cottarelli 2012). Because, simply, the fiscal multiplier is higher under the zero bound and depression, which is something undermined by the Troika (Gordon et al. 2013)...

This is not to say that rules are always suboptimal in a second-best environment. On the contrary, Lai and Chin (2010) show that Friedman's rule can become an effective policy tool in correcting capital market imperfections while Matsuoka (2011) argues that a combination of Friedman's rule with the proper discount window policy can achieve efficiency regardless bank industry structure. The problem with Friedman's rule lies rather in that under a second-best environment in which physical and human capital both deteriorate and the available tax instruments cannot address both of these problems, Friedman's rule can be of no help (see e.g. Petrucchi 2011) though it would be indispensable to policymaking if there were no tax-instrument availability problem, i.e. in a first-best setting (Abel 1987). The persistence of Cottarelli (2012) and DeLong et al. (2012) among others, on the primacy of fiscal policy in a second-best environment should be assessed from this perspective, too. Nevertheless, it should be investigated whether a loose monetary policy prescription (Greenlaw et al. 2013) controlling physical capital and allowing thereby tax instruments to focus on human capital control, can restore in an overlapping generations framework the first-best, requiring subsequently the satisfaction of Friedman's rule, too.

\section{Concluding Remarks}

Anyway, what is socially optimal is certainly subjective and given that the planner is a democratically elected government, the content of social optimality is judged by the median voter. Ever since the Great Depression of the 1930 's, the choice available to the electorate is the selection of the incumbent from political parties focusing on the Phillips curve and favoring this or the other policy instrument. It is clearly an election choice focusing on the 
short-run, "as if any improvement, however slight, in control of the cycle justified any sacrifice, however large, in the long-run efficiency, or prospects for growth of the economic system" (Friedman 1948, p.245). Since the 1930's, the voter is being called for to choose among the various discretionary policies but never between discretion as such and the "rule of law" as Friedman (1948, p.246) would put it. The closest an economy can come to its long-run perspective is through Friedman's k-percent rule, which again is a monetarist thesis connected with the Phillips curve, too.

The voter should certainly have the opportunity to make up its mind by knowing at least what a long-run policy focus would involve as well. It appears that there should also be a political party aligned with The Chicago School of Thought, with the Simons-Fisher-Friedman tradition, since it is the only one persisting in the reconciliation between the short- and the long-run policy-wise: It does so by wanting to institutionalize a Chicago-rule constraint, a balanced-budget constraint, no open-market operations, and a $100 \%$ reserve requirement ratio, the latter being interpreted as in the introductory Section.

Under the interpretation of the Chicago School advanced via this tract, commercial banking becomes the cornerstone of the system. By doing so, the system places itself in the hands of commercial banks, the task of social planning becomes one shared equally by the private bank and the political authority, and the latter can only be hoping that the bank will not abuse its power. Consequently, Fisher's scheme would be much more helpful towards this direction. What the bank loses economically is gained socio-politically. If the bank does abuse power and the government does not choose to adopt a cooperative-game short of interaction with it, the subsequent conflict will jeopardize the whole system right from its roots. At the other end, the bank becoming an informal non-elected government partner in social welfare decisionmaking, absolved thereby from the trade-offs imposed on this decisionmaking by Arrow's impossibility theorem, may have to confront the would-be "compromises" implied by this theorem for the positions taken by the elected incumbent.

Under the Chicago policy guidelines, the political arrangement becomes internal to the economic sphere and to the phenomenon of money itself. The two psychological elements about money that are required for a functioning money economy are the security of its general recognition as a means of payments, trusting that this recognition will not break down in the future. Chicago rule and Chicago tradition guarantee the part of trust to the extent that commercial banks guarantee the part of security, echoing Keynes' $(1923, \mathrm{p} .1)$ word of caution: "When the value of money changes, it does not change equally for all persons or for all purposes", which is of particular importance within an intergenerational context. It has been shown that the Chicago rule and subsequently, the entire Chicago policy package may be non-optimal under various second-best settings (see e.g. Gahvari and Micheletto 2012).

\section{References}

Abel, Andrew. (1987). Optimal Monetary Growth. Journal of Monetary Economics, 19, 437-50. http://dx.doi.org/10.1016/0304-3932(87)90008-0

Alper, Emre C. et al. (2008). The Welfare Effects of Government's Preferences over Spending and Its Financing. Economic Modelling, 25, 1-12. http://dx.doi.org/10.1016/j.econmod.2007.04.005

Aristotle. (1934). Nicomachean Ethics. Translated by H. Rackham, Harvard University Press, Cambridge, MA; William Heinemann Ltd, London.

Bailey, Martin J. (1956). The Welfare Cost of Inflationary Finance. Journal of Political Economy, 64(2), 93-110. http://dx.doi.org/10.1086/257766

Baltensperger, Ernst, \& Thomas J. Jordan. (1997). Seigniorage, Banking, and the Optimal Quantity of Money. Journal of Banking \& Finance, 21(6), 781-796. http://dx.doi.org/10.1016/S0378-4266(97)00008-3

Barro, Robert J. (1982). Measuring the Fed's Revenue from Money Creation. Economic Letters, 10(3-4), 327-332. http://dx.doi.org/10.1016/0165-1765(82)90074-X

Benes, Jaromir, \& Michael Kumhof. (2012). The Chicago Plan Revisited. Working Paper 12/2012, IMF.

Berti, Katia et al. (2013). Effects of Fiscal Consolidation Envisaged in the 2013 Stability and Convergence Programmes on Public Debt Dynamics in EU Member States. European Economy Economic Papers 504, European Commission.

Chari, V.V., Lawrence J. Christiano, \& Patrick J. Kehoe. (1996). Optimality of the Friedman Rule in Economies with Distorting Taxes. Journal of Monetary Economics, 37, 203-223. http://dx.doi.org/10.1016/S0304-3932(96)90034-3 
Correia, Isabel, \& Pedro Teles. (1996). Is the Friedman Rule Optimal when Money is an Intermediate Good? Journal of Monetary Economics, 38, 223-244. http://dx.doi.org/10.1016/S0304-3932(96)01276-7

Cottarelli, Carlo. (2012). Fiscal Adjustment: Too Much of a Good Thing? Vox (February 8). Retrieved from www.voxeu.org/index.php?q=node/7604

Dadush, Uri et al. (2010). Paradigm Lost: The Euro in Crisis. Carnegie Endowment for International Peace. Retrieved from www.CarnegieEndowment.org/EuroCrisis

Diamond, Douglas W., \& Philip H. Dybvig. (1983). Bank Runs, Deposit Insurance, and Liquidity. Journal of Political Economy, 91, 401-419. http://dx.doi.org/10.1086/261155

Diamond, Douglas W., \& Philip H. Dybvig. (1986). Banking Theory, Deposit Insurance, and Bank Regulation. The Journal of Business, 59(1), 55-68. http://dx.doi.org/10.1086/296314

Diamond, Peter A. (1965). National Debt in a Neoclassical Growth Model. American Economic Review, 55(5), Part 1, 1126-1150.

Douglas, Paul H. et al. (1939). A Program for Monetary Reform. Retrieved from http://home.comcast.net/ zthustra/pdf/a_program_for_monetary_reform.pdf

Fisher, Irving. (1936). 100\% Money and the Public Debt. Economic Forum, April-June, 406-420.

Friedman, Milton. (1948). A Monetary and Fiscal Framework for Economic Stability. American Economic Review, $38(3), 245-264$.

Friedman, Milton. (1953). Discussion of the Inflationary Gap. In Milton Friedman (Ed.), Essays in Positive Economics (pp.253-257). Chicago University Press, Chicago.

Friedman, Milton. (1960). A Program for Monetary Stability. Fordham University Press, New York.

Friedman, Milton. (1969). The Optimum Quantity of Money and Other Essays. Aldine Publishing Company, Chicago.

Friedman, Milton. (1971). Government Revenue from Inflation. Journal of Political Economy, 79, 846-856. http://dx.doi.org/10.1086/259791

Gahvari, Firouz. (2007). The Friedman rule: Old and New. Journal of Monetary Economics, 54, 581-589. http://dx.doi.org/10.1016/j.jmoneco.2006.06.008

Gahvari, Firouz, \& Luca Micheletto. (2012). Monetary Policy and Redistribution: What Can or Cannot be Neutralized with Mirrleesian Taxes. Working Paper 2012:5, Uppsala Center for Fiscal Studies.

Giraud, Gaël, \& Antonin Pottier. (2012). Debt-Deflation versus the Liquidity Trap: The Dilemma of Nonconventional Monetary Policy. Working Paper 2012.64, Centre d'Economie de la Sorbonne.

Gordon, J. et al. (2013). Greece: Ex Post Evaluation of Exceptional Access under the 2010 Stand-By Arrangement. IMF Country Report No. 13/156.

Greenlaw, David et al. (2013). Crunch Time: Fiscal Crises and the Role of Monetary Policy. U.S. Monetary Policy Forum, New York City. http://dx.doi.org/10.3386/w19297

Guidotti, Pablo, \& Carlos Vegh. (1993). The Optimal Inflation Tax when Money Reduces Transaction Costs. Journal of Monetary Economics, 31, 189-205. http://dx.doi.org/10.1016/0304-3932(93)90044-G

Hung, Fu-Sheng. (2005). Optimal Composition of Government Public Capital Financing. Journal of Macroeconomics, 27, 704-723. http://dx.doi.org/10.1016/j.jmacro.2004.03.006

Ireland, Peter. (1996). The Role of Countercyclical Monetary Policy. Journal of Political Economy, 104, 704-723. http://dx.doi.org/10.1086/262039

Keister, Todd, \& McAndrews, James. (2009). Why Are Banks Holding So Many Excess Reserves? Staff Report 380, Federal Reserve Bank of New York.

Keynes, John Maynard. (1923). The Consequences to Society of Changes in the Value of Money. In John Maynard Keynes (Ed.), A Tract on Monetary Reform (Ch. I, pp.1-30). Macmillan \& Co, London.

Kimbrough, Kent P. (1986). The Optimum Quantity of Money Rule in the Theory of Public Finance. Journal of Monetary Economics, 18, 277-284. http://dx.doi.org/10.1016/0304-3932(86)90040-1

Kotlikoff, Laurence J., \& Leamer, Edward. (2009). A Banking System We Can Trust. Commentary, Forbes.com. Retrieved from http://people.bu.edu/kotlikoff/newweb/Abankingsystemwecantrust_4_2009.pdf 
Lai, Ching-Chong, \& Chi-Ting Chin. (2010). (In)determinacy, Increasing Returns, and the Optimality of the Friedman Rule in an Endogenously Growing Open Economy. Economic Theory, 44, 69-100. http://dx.doi.org/10.1007/s00199-009-0457-x

Mankiw, Gregory N. (1987). The Optimal Collection of Seigniorage - Theory and Evidence. Journal of Monetary Economics, 20, 327-341. http://dx.doi.org/10.1016/0304-3932(87)90019-5

Matsuoka, Tarishi. (2011). Monetary Policy and Banking Structure. Journal of Money, Credit and Banking, 43, 1109-1129. http://dx.doi.org/10.1111/j.1538-4616.2011.00419.x

Mulligan, Casey, \& Xavier Sala-i-Martin. (1997). The Optimum Quantity of Money: Theory and Evidence. Journal of Money, Credit, and Banking, 29, 687-715. http://dx.doi.org/10.2307/2953658

Nelson, Edward. (2007). Why Money Growth Determines Inflation in the Long Run: Answering the Woodford Critique. Journal of Money, Credit and Banking, 40(8), 1791-1814. http://dx.doi.org/10.1111/j.1538-4616.2008.00183.x

Petrucci, Alberto. (2011). Nonoptimality of the Friedman Rulewith Capital Income Taxation. Journal of Money, Credit, and Banking, 43, 163-83. http://dx.doi.org/10.1111/j.1538-4616.2010.00369.x

Phelps, Edmunds S. (1973). Inflation in the Theory of Public Finance. Swedish Journal of Economics, 75, 67-82. http://dx.doi.org/10.2307/3439275

Qi, Jianping. (1994). Bank Liquidity and Stability in an Overlapping Generations Model. Review of Financial Studies, 7, 389-417. http://dx.doi.org/10.1093/rfs/7.2.389

Reich, Jens. (2011). Seigniorage - Where does it come from and who gets it? An institutional perspective on currency creation. 15th FMM Conference, Berlin, October 28th - 29th, 2011. Retrieved from http://www.boeckler.de/pdf/v_2011_10_27_reich.pdf

Rothbard, Murray N. (2008). The Mystery of Banking (2nd ed.). Ludwig von Mises Institute, Auburn, Alabama.

Simons, Henry C. (1934). A Positive Program for Laissez Faire: Some Proposals for a Liberal Economic Policy. Public Policy Pamphlets, No. 15. Chicago University Press, Chicago.

Simons, Henry C. (1936). Rules versus Authorities in Monetary Policy. Journal of Political Economy, 44, 1-30. http://dx.doi.org/10.1086/254882

Smith, Bruce D. (2003). Taking Intermediation Seriously. Journal of Money, Credit and Banking, 35(6), Part 2: Recent Developments inMonetary Economics, 1319-1357. http://dx.doi.org/10.1353/mcb.2004.0036

Tavlas, George S. (1997). Chicago, Harvard, and the Doctrinal Foundations of Monetary Economics. Journal of Political Economy, 105, 153-177. http://dx.doi.org/10.1086/262069

Tobin, James. (1963). Commercial Banks as Creators of Money. In Deane Carson (Ed.), Banking and Monetary Studies (pp. 408-419). Richard D. Irwin. Homewood, IL. 